ISSN : 2356-3966

\title{
PENGARUH GAYA KEPEMIMPINAN DAN BUDAYA ORGANISASI TERHADAP KOMITMEN ORGANISASI DAN KINERJA PEGAWAI (Studi Pada Badan Pengembangan Sumberdaya Manusia Provinsi Maluku)
}

\author{
Baretha Meisar Titioka ${ }^{1}$, Astrid J.D. Siahainenia ${ }^{2}$ \\ Politeknik Negeri Ambon ${ }^{1}$ \\ Badan Pengembangan Sumber Daya Manusia Provinsi Maluku ${ }^{2}$
}

\section{A R T I C L E I N F O}

Keywords: Leadership Style, Organization Culture, Organization Commitment, Employee Performance

\section{Kata Kunci:}

Gaya Kepemimpinan, Budaya

Organisasi, Komitmen

Organisasi dan Kinerja Pegawai.

Corresponding author:

Baretha Meisar Titioka

titiokabarce@yahoo.com
Abstract : This study aims to discuss the leadership style and organizational culture of organizational commitment and performance at the Maluku Provincial Human Resources Development Agency. The population of this study was 65 Civil Servants in the Maluku Province Education and Training Agency. The collected data analyzed using descriptive statistics and inferential statistics through Partial Least Square (PLS) analysis. The results showed that the leadership style variable had a positive and significant effect on organizational commitment. The influence of organizational culture on organizational commitment is positive. The influence of leadership style on employee performance is positive and significant. Positive and significant organizational performance on employee performance and positive and significant organizational commitment to employee performance. To get the expected employee improvement within the Maluku Provincial Human Resources Development Agency improve its leadership style and organizational culture so that the organizational commitment increases and increases in employee needs.

Abstrak: Penelitian ini bertujuan untuk menguji pengaruh gaya kepemimpinan dan budaya organisasi terhadap komitmen organisasi dan kinerja pegawai pada Badan Pengembangan Sumberdaya Manusia Provinsi Maluku. Populasi dari penelitian ini adalah seluruh Pegawai Negeri Sipil pada Badan Pendidikan dan Pelatihan Provinsi Maluku sebanyak 65 orang. Data yang terkumpul kemudian dianalisa menggunakan statistik deskriptifdan statistik inferensial melalui pendekatan Partial Least Square (PLS). Hasil penelitian menunjukan bahwa variable gaya kepemimpinan berpengaruh positif dan signifikan terhadap komitmen organisasi. Pengaruh budaya organsiasi terhadap komitmen organisasi adalah positif. Pengaruh gaya kepemimpinan terhadap kinerja pegawai adalah positif dan signifikan. Budaya organisasi berpengaruh positif dan signifikan terhadap kinerja pegawai serta komitmen organisasi berpengaruh positif dan signifikan terhadap kinerja pegawai. Untuk mendapatkan perbaikan kinerja pegawai diharapkan pegawai di lingkungan Badan Pengembangan Sumberdaya Manusia Provinsi Maluku memperbaiki model gaya kepemimpinannya dan budaya organisasinya sehingga komitmen organisasinya meningkat dan berdampak pada kinerja pegawai. 


\section{PENDAHULUAN}

\section{Latar Belakang}

Sumber daya manusia merupakan tokoh sentral dalam setiap organisasi/lembaga baik swasta maupun pemerintah untuk menggerakan lembaga tersebut sesuai dengan tujuan yang digariskan dengan mengutamakan pelayanan kepada publik. Organisasi yang berhasil dalam mencapai tujuan serta mampu memenuhi tanggung jawab sosialnya akan sangat tergantung pada para manajernya (pimpinan). Salah satu faktor keberhasilan seorang pemimpin adalah pemimpin tersebut harus mampu mempengaruhi perilaku anggotanya serta mengarahkan anggotanya untuk mencapai visi, misi dan tujuan organisasi tersebut. Hal ini ditegaskan oleh Menon (2002) yang menyatakan bahwa Kualitas dari pemimpin seringkali dianggap sebagai faktor terpenting dari keberhasilan atau kegagalan organisasi. Bahwa kepemimpinan juga memiliki kompleksitas dan dinamika yang tinggi dalam pengelolaan suatu organisasi. Menurut Hughes (2006) kepemimpinan itu memiliki kompleksitas yang melibatkan tiga hal utama yakni, pemimpin, pengikut dan situasi.

Penilaian kinerja di lingkungan pegawai negeri sipil (PNS) dikenal dengan sebutan penilaian pelaksanaan pekerjaan (Peraturan Pemerintah Nomor 10 Tahun 1979). Penilaian kinerja tersebut dilaksanakan menggunakan daftar penilaian pelaksanaan pekerjaan (DP3), dengan unsur-unsur yang terdapat di dalamnya, meliputi : kesetiaan, prestasi kerja, tanggung jawab, ketaatan, kejujuran, kerjasama, prakarsa dan kepemimpinan (hanya dinilai bagi Pegawai Negeri Sipil yang berpangkat Pengatur Muda golongan ruang II/a keatas yang memangku suatu jabatan). Namun karena adanya perubahan regulasi yang dituntut dengan perkembangan keadaan dan kebutuhan hukum dalam pembinaan Pegawai Negeri Sipil yang tidak sesuai lagi maka, pemerintah mengeluarkan Peraturan Pemerintah Nomor 46 Tahun 2011 tentang Penilaian Prestasi Kerja Pegawai Negeri Sipil yang terdiri atas unsur SKP (Sasaran Kerja Pegawai) dan Perilaku Kerja.

Sebagai salah satu Instansi Pemerintah Daerah, Badan Pengembangan Sumberdaya Manusia Provinsi Maluku di tuntut untuk meningkatkan kinerja pegawainya. Sejak dibentuk pada tahun 1992 sampai dengan saat ini, institusi Badan Pengembangan Sumberdaya Manusia Provinsi Maluku telah mengalami perubahan dan perkembangan baik dari aspek kelembagaan atau organisasi maupun dari aspek kepemimpinan.

Sesuai Rencana Strategis Badan Pengembangan Sumberdaya Manusia Provinsi Maluku, maka Visinya yaitu "Menjadi Pusat Peningkatan dan Pengembangan Kompetensi SDM Aparatur Daerah Yang Profesional Dijiwai Semangat Siwalima Dalam Membangun Maluku Berbasis Kepulauan”, dan untuk mewujudkan Visi diatas, ditetapkan Misi BPSDM Provinsi Maluku, yaitu :

1. Mengoptimalkan penyelenggaraan diklat yang berkualitas.

2. Melahirkan peserta didik yang kompteten ditandai dengan aparatur yang kreatif dan inovatif.

3. Mewujudkan aparatur yang bersih guna membangun Maluku berbasis kepulauan secara berkelanjutan.

Penelitian ini mengambil sampel pada pegawai Badan Pengembangan Sumberdaya Manusia Provinisi Maluku, dimana peran sumber daya manusia sebagai faktor yang sangat signifikan. Hasil dari pra survey yang peneliti lakukan di Badan Pengembangan Sumberdaya Manusia Provinisi Maluku menunjukan bahwa penelitian mengenai gaya kepemimpinan dan budaya organisasi selama ini belum pernah ada. Hal ini sesuai pengakuan dari Kepala Badan Pengembangan Sumberdaya Manusia Provinisi Maluku. Pernyataan yang sama juga dilontarkan oleh staf Badan Pengembangan Sumberdaya Manusia Provinisi Maluku mengenai belum banyak dilakukannya penelitian terhadap hal yang berhubungan dengan masalah tersebut, seperti misalnya masalah komitmen organisasi guna meningkatkan kinerja pegawai. Berangkat dari latar belakang masalah diatas maka peneliti mengambil judul "Pengaruh Gaya Kepemimpinan dan Budaya Organisasi Terhadap Komitmen Organisasi dalam meningkatkan Kinerja Pegawai". 


\section{Rumusan Masalah}

Berdasarkan uraian yang telah dikemukakan pada latar belakang masalah di atas, maka rumusan masalah dalam penelitian ini adalah sebagai berikut :

1. Bagaimana pengaruh gaya kepemimpinan terhadap komitmen organisasi pada Badan Pengembangan Sumberdaya Manusia Provinsi Maluku?

2. Bagaimana pengaruh budaya organisasi terhadap komitmen organisasi pada Badan Pengembangan Sumberdaya Manusia Provinsi Maluku?

3. Bagaimana pengaruh gaya kepemimpinan terhadap kinerja pegawai pada Badan Pengembangan Sumberdaya Manusia Provinsi Maluku?

4. Bagaimana pengaruh budaya organisasi terhadap kinerja pegawai pada Badan Pengembangan Sumberdaya Manusia Provinsi Maluku?

5. Bagaimana pengaruh komitmen organisasi terhadap kinerja pegawai pada Badan Pengembangan Sumberdaya Manusia Provinsi Maluku?

6. Bagaimana pengaruh gaya kepemimpinan terhadap kinerja pegawai melalui komitmen organisasi pada Badan Pengembangan Sumberdaya Manusia Provinsi Maluku?

7. Bagaimana pengaruh budaya organisasi terhadap kinerja pegawai Melalui komitmen organisasi pada Badan Pengembangan Sumberdaya Manusia Provinsi Maluku?

\section{Tujuan Penelitian}

Tujuan yang hendak dicapai pada penelitian ini adalah:

1. Menganalisis pengaruh gaya kepemimpinan terhadap komitmen organisasi pada Badan Pengembangan Sumberdaya Manusia Provinsi Maluku."

2. Menganalisis pengaruh budaya organisasi terhadap komitmen organisasi pada Badan Pengembangan Sumberdaya Manusia Provinsi Maluku.

3. Menganalisis pengaruh gaya kepemimpinan terhadap kinerja karyawan pada Badan Pengembangan Sumberdaya Manusia Provinsi Maluku.

4. Menganalisis pengaruh budaya organisasi terhadap kinerja karyawan pada Badan Pengembangan Sumberdaya Manusia Provinsi Maluku.

5. Menganalisis pengaruh komitmen organisasi terhadap kinerja karyawan pada Badan Pengembangan Sumberdaya Manusia Provinsi Maluku.

6. Menganalisis pengaruh gaya kepemimpinan terhadap kinerja pegawai melalui komitmen organisasi pada Badan Pengembangan Sumberdaya Manusia Provinsi Maluku.

7. Menganalisis pengaruh budaya organisasi terhadap kinerja pegawai melalui komitmen organisasi pada Badan Pengembangan Sumberdaya Manusia Provinsi Maluku.

\section{Gaya Kepemimpinan}

\section{TINJAUAN PUSTAKA}

Setiap pemimpin memiliki gaya kepemimpinan yang berbeda antara satu pemimpin dengan pemimpin yang lainnya, dan bukan suatu keharusan bahwa suatu gaya kepemimpinan lebih baik atau lebih buruk dibanding gaya kepemimpinan lainnya. Gaya kepemimpinan menunjukkan secara langsung maupun tidak langsung, mengenai keyakinan seorang pimpinan terhadap kemampuan bawahannya. Artinya gaya kepemimpinan adalah perilaku dan strategi, sebagai hasil kombinasi dari falsafah, keterampilan, sifat, sikap, yang sering diterapkan seorang pemimpin saat mencoba untuk mempengaruhi kinerja bawahannya. 


\section{Budaya Organisasi}

Organisasi merupakan hal yang tidak mungkin terlepas dari kehidupan bermasyarakat. Dalam suatu organisasi pasti terdapat ikatan budaya. ikatan budaya tersebut tercipta dan dibentuk oleh orang-orang yang ada dalam suatu organisasi. Budaya membedakan masyarakat satu dengan yang lain dalam cara berinteraksi dan bertindak menyelesaikan suatu pekerjaan. Budaya mengikat setiap anggota masyakarat dalam suatu organisasi menjadi satu kesatuan padangan dalam bertindak terutama untuk mencapai tujuan organisasinya.

Menurut Robbins \& Coulter (2012:51) budaya organisasi adalah nilai, prinsip, tradisi, dan sikap yang mempengaruhi cara bertindak anggota organisasi. Budaya organisasi juga harus diikuti oleh seluruh anggota organisasi. Budaya organisasi dibentuk melalui interaksi 4 (empat) faktor utama, yaitu: Personal and professional characteristics of people within the organization (characteristics of organizational members), organizational ethics, the employment relationship, and organizational structure (Jones dan George, 2008:415). Budaya organisasi merupakan faktor paling penting dalam suatu organisasi, Organisasi dengan budaya yang kuat dapat menarik perhatian seorang individu untuk bergabung dalam suatu organisasi. Budaya organisasi yang kuat dapat mendukung tercapainya tujuan organisasi karena budaya organisasi dapat membantu organisasi untuk mengarahkan karyawan untuk melakukan pekerjaan yang dengan baik, sehingga setiap karyawan perlu memahami dan mengimplementasikan budaya tersebut.

\section{Komitmen Organisasi}

Menurut Robert dan Kinicki (dalam Robert Kreitner, 2011) bahwa komitmen organisasi adalah cerminan dimana seorang karyawan dalam mengenali organisasi dan terikat kepada tujuan-tujuannya. Ini adalah sikap kerja yang penting karena orang -orang memiliki komitmen diharapkan dapat menunjukkan ketersediaannya untuk bekerja lebih keras demi mencapai tujuan organisasi dan memiliki hasrat yang lebih besar untuk tetap bekerja di suatu perusahaan.

\section{Kinerja Pegawai}

Konsep kinerja organisasi juga menggambarkan bahwa setiap organisasi publik memberikan pelayanan kepada masyarakat dan dapat dilakukan pengukuran kinerjanya dengan menggunakan indikator-indikator kinerja yang ada untuk melihat apakah organisasi tersebut sudah melaksanakan tugasnya dengan baik dan untuk mengetahui tujuannya sudah tercapai atau belum. Menurut Gibson dalam Moeheriono (2012) ada tiga faktor yangberpengaruh terhadap kinerja seseorang, yaitu:

1. Faktor individu : kemampuan, keterampilan, latar belakang keluarga,pengalaman tingkat sosial dan demografi seseorang.

2. Faktor psikologis : persepsi, peran, sikap, kepribadian, motivasi dan kepuasankerja.

3. Faktor organisasi : struktur organisasi, desain pekerjaan, kepemimpinan, sistempenghargaan (reward system). Tsui et all (1997) dalam mas'ud (2004) merumuskan indikator-indikator kinerja karyawan sebagai berikut :

a. Kualitas kerja karyawan

b. Standar profesional

c. Kuantitas kerja karyawan

d. Kreativitas karyawan

\section{Hasil Penelitian Sebelumnya}

Beberapa penelitian yang telah dilakukan oleh beberapa peneliti mengenai gaya kepemimpinan, budaya organisasi, komitmen organisasi dan kinerja karyawan diantaranya ; 
1. Penelitian oleh Tambengi et al (2016) menyatakan bawah faktor yang paling dominan berpengaruh terhadap kinerja karyawan adalah budaya organisasi hal ini di buktikan dengan nilai standardized coefficient yang terbesar. Sementara budaya organisasi berpengaruh secara positif dan signifikan terhadap kinerja karyawan. Semakin baik budaya organisasi, maka kinerja karyawan akan meningkat. Gaya kepemimpinan berpengaruh positif terhadap kinerja karyawan artinya apabila gaya kepemimpinan semakin baik, maka kinerja karyawan akan meningkat.

2. Penelitian oleh Utami (2016) menunjukkan bahwa budaya organisasi, gaya kepemimpinan dan komitmen organisasi terhadap kinerja karyawan Badan Narkotika Provinsi Bengkulu memiliki pengaruh baik secara simultan maupun parsial.

3. Penelitian oleh Hasniaty (2017) menunjukkan bahwa variabel gaya kepemimpinan, budaya organisasi dan komitmen organisasi secara bersama-sama berpengaruh secara positif dan signifikan terhadap kinerja pegawai Dinas Pertanian Kabupaten Mamuju. Hasil analisis menunjukkan bahwa dari ketiga variabel yang diteliti, variabel komitmen organisasi mempunyai pengaruh paling dominan terhadap kinerja pegawai Dinas Pertanian Kabupaten Mamuju.

\section{Kerangka Konseptual}

Berdasarkan kajian empiris tentang pengaruh gaya kepemimpinan dan budaya organisasi terhadap komitmen organisasi dan kinerja pegawai, dapat dilihat pada gambar berikut ini :

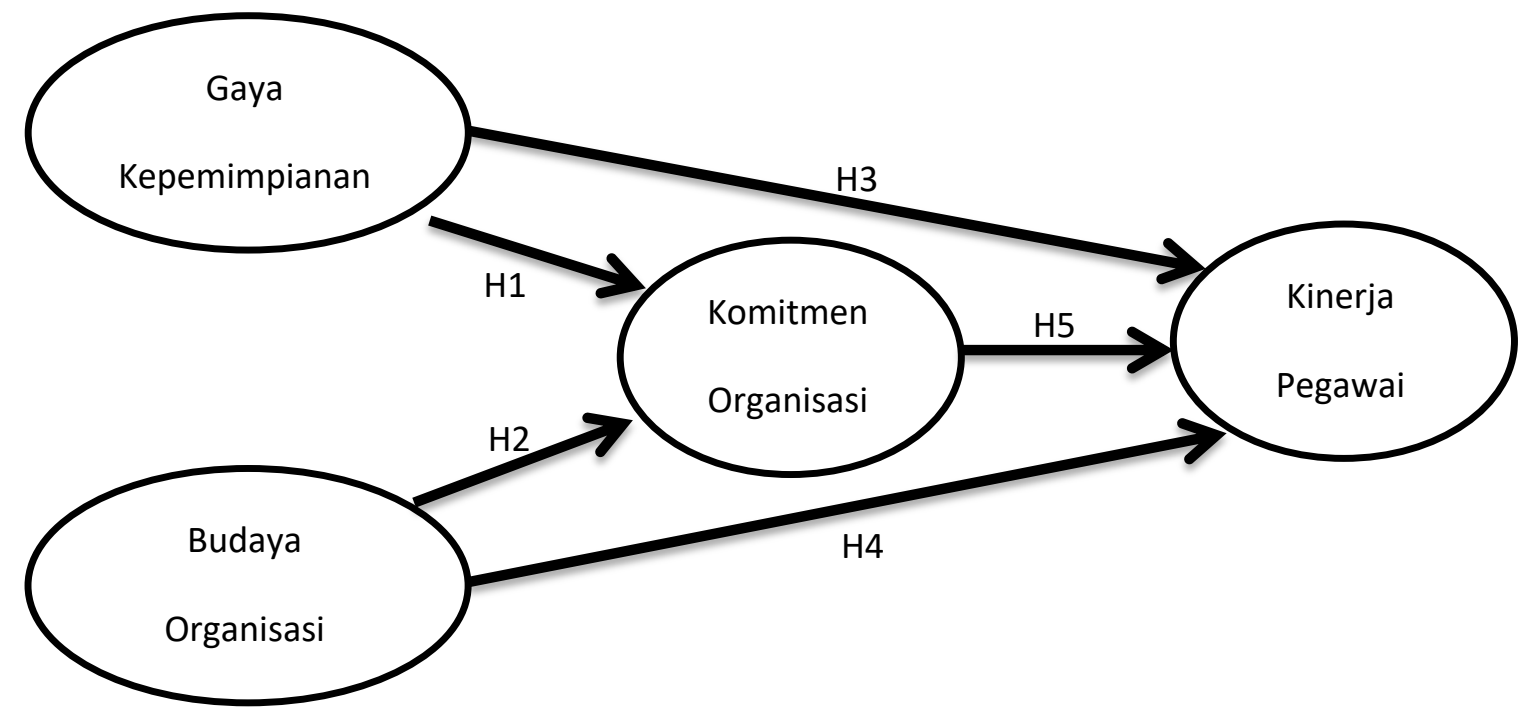

\section{Gambar 1. Kerangka Teori}

\section{Hipotesis}

Hipotesis penelitian merupakan dugaan awal/kesimpulan sementara hubungan pengaruh antara variabel independen terhadap variabel dependen sebelum dilakukan penelitian dan harus dibuktikan melalui penelitian. Adapun hipotesis penelitian ini adalah :

H1 : Gaya kepemimpinan berpengaruh positif terhadap komitmen organisasi pada Badan Pengembangan Sumberdaya Manusia Provinsi Maluku.

H2 : Budaya organisasi berpengaruh positif terhadap komitmen organisasi pada Badan Pengembangan Sumberdaya Manusia Provinsi Maluku.

H3 : Gaya kepemimpinan berpengaruh positif terhadap kinerja pegawai pada Badan Pengembangan Sumberdaya Manusia Provinsi Maluku. 
H4 : Budaya organisasi berpengaruh positif terhadap kinerja pegawai pada Badan Pengembangan Sumberdaya Manusia Provinsi Maluku

H5 : Komitmen organisasi berpengaruh positif terhadap kinerja pegawai pada Badan Pengembangan Sumberdaya Manusia Provinsi Maluku.

H6 : Gaya kepemimpinan berpengaruh positif terhadap kinerja pegawai melalui komitmen organisasi pada Badan Pengembangan Sumberdaya Manusia Provinsi Maluku.

H7 : Budaya organisasi berpengaruh positif terhadap kinerja pegawai melalui komitmen organisasi pada Badan Pengembangan Sumberdaya Manusia Provinsi Maluku.

\section{METODOLOGI PENELITIAN}

\section{Jenis dan Sumber Data}

Jenis penelitian yakni survey, data yang dikumpulkan berupa data yang bersifat kuantitatif dan kualitatif. Sumber data yang dipergunakan adalah data primer yaitu data yang diperoleh langsung dari obyek penelitian dalam hal ini Badan Pengembangan Sumberdaya Manusia Provinsi Maluku. Sedangkan data sekunder yaitu Data yang diperoleh dari berbagai sumber di luar objek penelitian, seperti literatur-literatur, telaah pustaka dan bahan-bahan tertulis lainnya yang berkaitan dengan penelitian ini.

\section{Populasi dan Sampel}

Populasi dari penelitian ini adalah seluruh Pegawai Negeri Sipil pada Badan Pengembangan Sumberdaya Manusia Provinsi Maluku, sebanyak 65 orang. Melihat populasi yang tidak terlalu besar yaitu jumlahnya kurang dari seratus orang, maka penelitian ini menggunakan sampel jenuh yaitu semua populasi digunakan sebagai sampel (Arikunto $1998: 120$ ). Berikut ini dijelaskan sampel penelitian sebagamana tabel dibawah ini :

Tabel. 1 Klasifikasi Jabatan Pegawai Badan Pengembangan Sumberdaya Manusia Provinsi Maluku

\begin{tabular}{clcc}
\hline \multicolumn{1}{c}{ JENIS JABATAN } & ESELON & JUMLAH \\
\hline 1 & Kepala Badan & II & 1 \\
2 & Sekretaris Badan & III & 1 \\
3 & Kepala Bidang & III & 3 \\
4 & Kepala Sub Bidang & IV & 9 \\
5 & Widyaiswara & Fungsional & 18 \\
6 & Staf Pelaksana & -- & 33 \\
\hline
\end{tabular}

Sumber : data primer diolah

\section{Metode Pengumpulan Data}

Metode pengumpulan data yang digunakan adalah :

1. pengamatan langsung, untuk memperoleh gambaran suasana tempat kerja, proses kerja dan hal-hal lain yang diperlukan.

2. Studi kepustakaan dilakukan dengan cara mempelajari berbagai literatur yang berkenaan dengan pokok permasalahan yang akan dikaji serta hasil-hasil penelitian sebelumnya, guna memperoleh landasan teoritis

3. Kuesioner berupa daftar pertanyaan tertulis.

4. Dokumentasi yakni pengumpulan data yang dilakukan melalui dokumen yang ada seperti laporan, dan catatancatatan lainnya. 


\section{Teknik Analisa Data}

Teknik analisa data dilakukan dengan langkah-langkah sebagai berikut :

\section{Statistik Deskriptif}

Analisis ini bertujuan mendapatkan gambaran mengenai jawaban responden mengenai variabel-variabel yang diteliti yang dilakukan dengan menggunakan teknik Analisis Indeks yang menggambarkan persepsi responden atas item-item pertanyaan yang diajukan. Teknik scoring yang dilakukan dalam penelitian ini adalah minimum 1 dan maksimum 5, maka perhitungan indeks jawaban responden dilakukan denganrumus sebagai berikut (Ferdinand, 2006) :

Nilai Indeks $=((\% \mathrm{~F} 1 \times 1)+(\% \mathrm{~F} 2 \times 2)+(\% \mathrm{~F} 3 \times 3)+(\% \mathrm{~F} 4 \times 4)+(\% \mathrm{~F} 5 \times 5)) / \mathrm{n}$

Dimana:

$\mathrm{F} 1=$ frekuensi responden yang menjawab 1

$\mathrm{F} 2$ = frekuensi responden yang menjawab 2

Dst, F5 = frekuensi responden yang menjawab 5

Skala pengukuran yang digunakan dalam penelitian ini adalah modifikasi skala Likert, yaitu dari 1 sampai 5 . Skala pengukuran untuk variabel gaya kepemimpinan, budaya organisasi, komitmen organisasi, dan kinerja pegawai diukur melalui modifikasi dengan poin yang disesuaikan dengan materi penelitian yang dikembangkan. Adapun penggunaan skala 1 - 5 untuk setiap jawaban responden selanjutnya dibagi ke dalam lima kategori yakni:

(1) Sangat Setuju (SS) diberi skor 5

(2) Setuju (S) diberi skor 4

(3) Netral (N) diberi skor 3

(4) Tidak Setuju (TS) diberi skor 2

(5) Sangat Tidak Setuju (STS) diberi skor 1

Setelah skor diperoleh lalu dicari rata-rata skor per responden. Data responden secara individu didistribusikan berdasarkan kriteria tertentu, sehingga dapat dideskripsikan distribusi jawabannya. Dengan menggunakan kriteria tiga kotak, maka angka indeks 1 hingga 5 dengan rentang sebesar 4 dibagi tiga menghasilkan setiap rentang 1,3 yang akan digunakan sebagai dasar intepretasi nilai indeks, dimana dalam penelitian ini adalah sebagai berikut:

$1,0-1,3=$ Rendah
$1,4-2,7=$ Sedang
$2,8-5,0=$ Tinggi

\section{Statistik Inferensial}

Dalam penelitian ini analisis data menggunakan pendekatan Partial Least Square (PLS). PLS adalah model persamaan Structural Equation Modeling (SEM) yang berbasis komponen atau varian. Menurut Ghozali (2006), PLS merupakan pendekatan alternatif yang bergeser dari pendekatan SEM berbasis kovarian menjadi berbasis varian. SEM yang berbasis kovarian umumnya menguji kausalitas/teori sedangkan PLS lebih bersifat predictive model. PLS merupakan metode analisis yang powerfull (Ghozali, 2006), karena tidak didasarkan pada banyak asumsi. Misalnya, data harus terdistribusi normal, sampel tidak harus besar. Selain dapat digunakan untuk mengkonfirmasi teori, PLS juga dapat digunakan untuk menjelaskan ada tidaknya hubungan antar variabel laten. PLS dapat sekaligus menganalisis konstruk yang dibentuk dengan indikator reflektif dan formatif.

Menurut Ghozali (2006) tujuan PLS adalah membantu peneliti untuk tujuan prediksi. Model formalnya mendefinisikan variabel laten adalah linear agregat dari indikator-indikatornya. Weight estimate untuk menciptakan 
komponen skor variabel laten didapat berdasarkan bagaimana inner model (model struktural yang menghubungkan antar variabel laten) dan outer model (model pengukuran yaitu hubungan antara indikator dengan konstruknya) dispesifikasi. Hasilnya adalah residual variance dari variabel dependen.

\section{HASIL PENELITIAN DAN PEMBAHASAN}

\section{Analisis Deskriptif}

\section{Karakteristik Responden}

Karakteristik responden, merupakan gambaran tentang umur dan jenis kelamin dan latar belakang pendidikan. Adapun karakteristik responden disajikan pada tabel 3 di bawah ini :

Tabel. 3 Karakteristik Responden

\begin{tabular}{|c|c|c|c|c|}
\hline No & Karakteristik & & $\begin{array}{l}\text { Jumlah } \\
\text { (Orang) }\end{array}$ & $\begin{array}{c}\text { Presentase } \\
(\%)\end{array}$ \\
\hline \multirow[t]{5}{*}{1} & Umur & & & \\
\hline & $19 \mathrm{~s} / \mathrm{d} 29$ Tahun & & 9 & $13,85 \%$ \\
\hline & $30 \mathrm{~s} / \mathrm{d} 40$ Tahun & & 32 & $49,23 \%$ \\
\hline & $>41$ Tahun keatas & & 24 & $36,92 \%$ \\
\hline & & Jumlah & 65 & $100,00 \%$ \\
\hline \multirow[t]{4}{*}{2} & Jenis Kelamin & & & \\
\hline & Laki - Laki & & 38 & $58,46 \%$ \\
\hline & Perempuan & & 27 & $41,54 \%$ \\
\hline & & Jumlah & 65 & $100,00 \%$ \\
\hline \multirow[t]{5}{*}{3} & Latar Belakang Pendidikan & & & \\
\hline & SMA & & 13 & $20 \%$ \\
\hline & $\mathrm{S} 1$ & & 47 & $74 \%$ \\
\hline & S2 & & 5 & $6 \%$ \\
\hline & & Jumlah & 65 & $100 \%$ \\
\hline \multirow[t]{5}{*}{4} & Masa Kerja & & & \\
\hline & $3 \mathrm{~s} / \mathrm{d} 13$ Tahun & & 22 & $33,84 \%$ \\
\hline & 14 s/d 24 Tahun & & 16 & $24,62 \%$ \\
\hline & $>25$ Tahun keatas & & 27 & $41,54 \%$ \\
\hline & & Jumlah & 65 & $100,00 \%$ \\
\hline \multirow[t]{4}{*}{5} & Status & & & \\
\hline & Nikah & & 63 & $96,92 \%$ \\
\hline & Belum Nikah & & 2 & $3,08 \%$ \\
\hline & & Jumlah & 65 & $100,00 \%$ \\
\hline
\end{tabular}

Sumber : data primer, diolah

Berdasarkan informasi yang disajikan dari Tabel 3 di atas, maka dapat dideskripsikan bahwa responden berdasarkan umur didominasi oleh responden berumur 30 sampai dengan 40 tahun sebesar $49.23 \%$,

mengindikasikan tingginya kuantitas karyawan dengan umur produktif yang bekerja pada Badan Pengembangan Sumberdaya Manusia Provinsi Maluku

Berdasarkan jenis kelamin, menunjukkan bahwa karyawan yang bekerja pada Badan Pengembangan Sumberdaya Manusia Provinsi Maluku, didominasi oleh laki-laki sebesar 58.46 \% sedangkan perempuan $41.54 \%$.

Untuk latar belakang pendidikan, latar belakang SMA yaitu 13 orang (20\%), latar belakang pendidikan S1 sebanyak 48 orang (74 \%) sedangkan S2 sebanyak 4 orang (6\%). 
Berdasarkan masa kerja dapat dijelaskan bahwa pegawai dengan masa kerja 3 s/d 13 Tahun sebanyak 22 orang (33,84\%), pegawai dengan masa kerja 14 s/d 24 Tahun sebanyak 16 orang (24,62\%), sedangkan pegawai dengan masa kerja $>25$ Tahun keatas sebanyak 27 orang $(41,54 \%)$.

Untuk status pernikahan dapat diuraikan sebagai berikut; pegawai yang sudah menikah sebanyak 63 orang (96,92\%), sedangkan pegawai yang belum menikah sebanyak 2 orang $(3,08 \%)$.

\section{Deskripsi Variabel Penelitian}

Analisis pada bagian ini untuk mendeskripsikan sebaran jawaban responden terhadap variabel penelitian.Variabel penelitian merupakan variabel laten (unobserve) sehingga deskripsinya akan dilakukan melalui indikator dari masing-masing variabel laten tersebut.

Deskripsi pada indikator dilakukan dengan menjelaskan sebaran jawaban responden pada sejumlah pertanyaan/pernyataan pada masing-masing indikator (variabel observe).

\section{Variabel Gaya Kepemimpinan}

Gaya Kepemimpinan merupakan berbagai pola tingkah laku yang disukai oleh pemimpin dalam proses mengarahkan dan mempengaruhi pekerja. (Stoner et.al,1996). Variabel ini diukur dengan lima indikator.

Secara lengkap distribusi frekuensi jawaban responden sebagai respon terhadap gaya kepemimpinan dituangkan dalam Tabel berikut :

Tabel. 4 Distribusi Frekuensi Responden Indikator Gaya Kepemimpinan

\begin{tabular}{|c|c|c|c|c|c|c|c|}
\hline \multirow{3}{*}{ No } & \multirow{3}{*}{ Pernyataan } & \multirow{2}{*}{\multicolumn{5}{|c|}{$\begin{array}{c}\text { Distribusi Jawaban Responden } \\
(\%)\end{array}$}} & \multirow{3}{*}{ Mean } \\
\hline & & & & & & & \\
\hline & & \multirow[t]{2}{*}{ STS } & \multicolumn{2}{|r|}{$\begin{array}{c}(\%) \\
\mathrm{N}\end{array}$} & $\mathrm{S}$ & \multirow[t]{2}{*}{ SS } & \\
\hline \multicolumn{6}{|c|}{ Gaya Kepemimpinan (X1) } & & \\
\hline 1 & Pemimpin sering memotivasibawahan & 1,5 & 10,8 & 29,2 & 33,8 & 24,6 & 3,69 \\
\hline 2 & $\begin{array}{l}\text { Pemimpin bergaul secara informal dengan } \\
\text { bawahan }\end{array}$ & & 7,7 & 32,3 & 40,0 & 20,0 & 3,72 \\
\hline 3 & $\begin{array}{l}\text { Pemimpin mengharapkan bawahan untuk } \\
\text { mematuhi } \\
\text { peraturan berkaitan dengan pekerjaan mereka }\end{array}$ & & 9,2 & 35,4 & 36,9 & 18,5 & 3,65 \\
\hline 4 & $\begin{array}{l}\text { Pemimpin menuntut bawahan memprioritaskan } \\
\text { pelaksanaan tugas dari pada urusan yang lain }\end{array}$ & 4,6 & 7,7 & 12,3 & 38,5 & 36,9 & 3,95 \\
\hline 5 & $\begin{array}{l}\text { Pemimpin memuji dan menghargai mereka yang } \\
\text { bekerja keras }\end{array}$ & 3,1 & 16,9 & 16,9 & 38,5 & 24,6 & 3,65 \\
\hline
\end{tabular}

Sumber : Data primer, diolah

Berdasarkan Tabel 4 tampak bahwa variabel gaya kepemimpinan memiliki rata-rata indeks indikator sebesar 3,73. Jika dinterpretasikan berdasarkan tabel skors interpretasi, maka mean tersebut dikategorikan tinggi. Artinya secara umum gaya kepemimpinan menjelaskan bahwa pemimpin ingin bawahannya memprioritaskan pekerjaan mereka dari pada urusan lain dan harus mematuhi peraturan yang berkaitan dengan pekerjaan mereka. Selain itu juga pemimpin sering bergaul dengan bawahan tanpa ada sekat atau kesenjangan antara pemimpin dan 
bawahan. Demikian pula pemimpin sering memotivasi bawahannya untuk bekerja keras dengan demikian pemimpin akan memuji dan menghargai mereka yang bekerja keras.

\section{Variabel Budaya Organisasi}

Budaya organisasi merupakan suatu sistem makna bersama yang dianutoleh anggota-anggotayang membedakan organisasi itu dari organisasi-organisasi lain. (Robbin, 2006). Pada penelitian ini digunakan empat indikator sebagai pengukur budaya organisasi.

Secara lengkap distribusi frekuensi jawaban responden sebagai respon terhadap budaya organisasi dituangkan dalam Tabel berikut :

Tabel.5 Distribusi Frekuensi Responden Indikator Budaya Organisasi

\begin{tabular}{|c|c|c|c|c|c|c|c|}
\hline \multirow{2}{*}{ No } & \multirow{2}{*}{ Pernyataan } & \multicolumn{5}{|c|}{ Distribusi Jawaban Responden (\%) } & \multirow{2}{*}{ Mean } \\
\hline & & STS & TS & $\mathrm{N}$ & $\mathrm{S}$ & SS & \\
\hline \multicolumn{8}{|c|}{ Budaya Organisasi (X2) } \\
\hline 1 & $\begin{array}{l}\text { Anggota organisasi dalam bekerja saling } \\
\text { mendukung dan terbuka }\end{array}$ & 6,2 & 10,8 & 18,5 & 35,4 & 29,2 & 3,71 \\
\hline 2 & $\begin{array}{l}\text { Dalam organisasi, anggota organisasi mencurahkan } \\
\text { seluruh kemampuannya untuk bekerja }\end{array}$ & 6,2 & 6,2 & 29,2 & 35,4 & 23,1 & 3,63 \\
\hline 3 & $\begin{array}{l}\text { Dalam organisasi, anggota organisasi } \\
\text { mengorganisasikan pekerjaannya bersama }\end{array}$ & 3,1 & 10,8 & 33,8 & 33,8 & 18,5 & 3,54 \\
\hline 4 & $\begin{array}{l}\text { Anggota organisasi bersikap hangat (ramah) dalam } \\
\text { Pergaulan }\end{array}$ & 3,1 & 9,2 & 29,2 & 30,8 & 27,7 & 3,71 \\
\hline
\end{tabular}

Sumber : Data primer, diolah

Berdasarkan Tabel 5 tampak bahwa variabel budaya organisasimemiliki rata-rata indeks indikator sebesar 3,65. Jika dinterpretasikan berdasarkan tabel skors interpretasi, maka mean tersebut dikategorikan tinggi. Artinya secara umumbudaya organisasi menjelaskan bahwa anggota organisasi dalam bekerja saling mendukung, terbuka serta bersikap ramah dalam pergaulan. Selain itu juga anggota organisasi mencurahkan seluruh kemampuannya untuk bekerja dan mengorganisasikan pekerjaannya bersama.

\section{Variabel Komitmen Organisasi}

Komitmen organsiasi adalah sikap yang merefleksikan loyalitas karyawan kepada organisasi dan merupakan suatu proses berkelanjutan dimana anggota organisasi mengungkapkan perhatian mereka terhadap organisasi, terhadap keberhasilan organisasi serta kemajuan yang berkelanjutan. (Luthans ,2006).

Variabel ini diukur dengan empat indikator.Secara lengkap distribusi frekuensi jawaban responden sebagai respon terhadap komitmen organisasi dituangkan dalam Tabel berikut :

Tabel. 6 Distribusi Frekuensi Responden Indikator Komitmen Organisasi

\begin{tabular}{lllllll}
\hline \multirow{2}{*}{ No } & Pernyataan & \multicolumn{3}{c}{ Distribusi Jawaban Responden (\%) } & Mean \\
\cline { 2 - 6 } & STS & TS & N & S & SS & \\
\hline $\begin{array}{l}\text { Komitmen Organisasi (Y1) } \\
1\end{array}$ & $\begin{array}{l}\text { Bersedia menerima semua macam penugasan agar } \\
\text { tetap bekerja dengan organisasi }\end{array}$ & 1,5 & 10,8 & 78,5 & 9,2 & 3,95 \\
& & & & & & \\
\hline 82 & JURNAL ILMIAH MANAJEMEN BISNIS DAN INOVASI UNIVERSITAS SAM RATULANGI \\
VOL.6 NO.2. MEI 2019, HAL.73-97
\end{tabular}




\begin{tabular}{|c|c|c|c|c|c|}
\hline 2 & $\begin{array}{l}\text { Membanggakan kepada orang lain bahwa } \\
\text { organisasi tempat bekerja adalah organisasi yang bagus }\end{array}$ & 15,4 & 75,4 & 9,2 & 3,94 \\
\hline 3 & Merasa bangga menjadi bagian dari organisasi & 32,3 & 58,5 & 9,2 & 3,77 \\
\hline 4 & $\begin{array}{l}\text { Organisasi benar-benar memberi inspirasi yang bagus } \\
\text { untuk berprestasi }\end{array}$ & 27,7 & 66,2 & 6,2 & 3,78 \\
\hline
\end{tabular}

Sumber : Data primer, diolah

Berdasarkan Tabel 6, tampak bahwa variabel komitmen organisasimemiliki rata-rata indeks indikator sebesar 3,86. Jika dinterpretasikan berdasarkan tabel skors interpretasi, maka mean tersebut dikategorikan tinggi. Artinya pegawai atau bawahan bersedia menerima semua macam penugasan agar tetap bekerja dengan organisasi yang benar-benar memberi inspirasi yang bagus untuk berprestasi sehingga pegawai atau bawahan merasa bangga menjadi bagian dari organisasi sehingga bawahan membanggakan kepada orang lain bahwa organisasi tempat bekerja adalah organisasi yang bagus.

\section{Variabel Kinerja Pegawai}

Kinerja pegawai merupakan perilaku nyata yang ditampilkan setiap orang sebagai prestasi kerja yang dihasilkan oleh karyawan sesuai dengan perannya dalam perusahaan (Rivai, 2005).

Variabel ini diukur dengan empat indikator. Secara lengkap distribusi frekuensi jawaban responden sebagai respon terhadap komitmen organisasi dituangkan dalam Tabel Berikut :

Tabel. 7 Distribusi Frekuensi Responden Indikator Kinerja Pegawai

\begin{tabular}{|c|c|c|c|c|c|c|c|}
\hline \multirow{2}{*}{ No } & \multirow{2}{*}{ Pernyataan } & \multicolumn{5}{|c|}{ Distribusi Jawaban Responden (\%) } & \multirow{2}{*}{ Mean } \\
\hline & & STS & TS & $\mathrm{N}$ & $\mathrm{S}$ & SS & \\
\hline \multicolumn{8}{|c|}{ Kinerja Pegawai (Y2) } \\
\hline 1 & $\begin{array}{l}\text { Pegawai dapat melaksanakan pekerjaan dengan } \\
\text { tepat waktu }\end{array}$ & 6,2 & 10,8 & 30,8 & 29,2 & 23,1 & 3,52 \\
\hline 2 & Pegawai selalu berinisiatif dalam setiap pekerjaannya & 6,2 & 10,8 & 40,0 & 29,2 & 13,8 & 3,34 \\
\hline 3 & Pengetahuan pegawai berkaitan dengan pekerjaannya & 4,6 & 12,3 & 27,7 & 38,5 & 16,9 & 3,51 \\
\hline 4 & $\begin{array}{l}\text { Pegawai memiliki tingkat kreativitas dalam } \\
\text { melaksanakan pekerjaannya }\end{array}$ & 62 & 20,0 & 38,5 & 29,2 & 6,2 & 3,09 \\
\hline 5 & $\begin{array}{l}\text { Pegawai dapat melaksanakan tugas sesuai prosedur } \\
\text { Organisasi }\end{array}$ & 6,2 & 12,3 & 30,8 & 29,2 & 21,5 & 3,48 \\
\hline 6 & Pegawai mampu melaksanakan pekerjaannya & 4,6 & 15,4 & 32,3 & 27,7 & 20,0 & 3,43 \\
\hline \multicolumn{7}{|c|}{ Rata-rata Indeks Indikator Kinerja Pegawai } & 3,39 \\
\hline
\end{tabular}

Sumber : Data primer, diolah

Berdasarkan Tabel 7, tampak bahwa variabel kinerja pegawaimemiliki rata-rata indeks indikator sebesar 3,39. Jika dinterpretasikan berdasarkan tabel skors interpretasi, maka mean tersebut dikategorikan tinggi. Artinya secara umum kinerja pegawai menjelaskan bahwa pegawai mampu melaksanakan pekerjaannya dengan tepat waktu sesuai dengan prosedur organisasi dan selalu berinisiatif dalam setiap pekerjaannya sesuai dengan tingkat pengetahuan dan kreativitas pegawai. 


\section{Analisis Inferensial}

Teknik pengolahan data dengan menggunakan metode SEM berbasis Partial Least Square (PLS) untuk menguji kualitas data, yaitu uji validitas dan uji realibilitas.Selain itu analisis data dengan menggunakan PLS ini juga untuk menguji hipotesis.

\section{Uji Kualitas Data}

Kesimpulan penelitian yang berupa jawaban atau pemecahan masalah penelitian, dibuat berdasarkan hasil proses pengujian data. Konsep yang digunakan dalam proses pengujian data yaitu, uji validitas dan uji realibilitas (Indriantoro dan Supomo, 2013:180). Adapun tahapan-tahapan uji kualitas data yaitu sebagai berikut.

1) Uji Validitas Konvergen

Uji validitas konvergen dinilai berdasarkan loading factor (korelasi antara skor item/skor komponen dengan skor konstruk). Rule of thumb yang digunakan dalam uji validitas konvergen nilai outer loading $>0,7 ;$ AVE $>$ 0,5; dan Communality> 0,5 (Jogiyanto dan Abdillah, 2009).

Tabel.8 Output Nilai Outer Loading Outer Loadings

\begin{tabular}{|c|c|c|c|c|}
\hline & Bud_Org (X2) & Gaya_Kep (X1) & Kinerja Peg (Y2) & Komit_Org (Y1) \\
\hline $\mathbf{x 1 1}$ & & 0.855217 & & \\
\hline $\mathbf{x 1 2}$ & & 0.755549 & & \\
\hline $\mathbf{x 1 3}$ & & 0.798540 & & \\
\hline $\mathbf{x 1 4}$ & & 0.822892 & & \\
\hline $\mathbf{x 1 5}$ & & 0.807943 & & \\
\hline $\mathbf{x} 21$ & 0.819676 & & & \\
\hline $\mathbf{x} 22$ & 0.708141 & & & \\
\hline $\mathbf{x 2 3}$ & 0.851203 & & & \\
\hline $\mathbf{x} 24$ & 0.835805 & & & \\
\hline y11 & & & & 0.747631 \\
\hline y12 & & & & 0.837280 \\
\hline y13 & & & & 0.791332 \\
\hline y14 & & & & 0.754213 \\
\hline y21 & & & 0.845090 & \\
\hline y22 & & & 0.780698 & \\
\hline y23 & & & 0.829259 & \\
\hline y24 & & & 0.855340 & \\
\hline y25 & & & 0.809712 & \\
\hline y26 & & & 0.847194 & \\
\hline
\end{tabular}

Sumber : Data primer, diolah

Berdasarkan Tabel 8 di atas tampak bahwa untuk semua nilai Outer loading indikator tiap variabel berada di atas atau sama dengan 0.7. Untuk variabel gaya kepemimpinan nilai tertinggi outer loading berada di 0.855217 yaitu X11, sedangkan terendah berada di 0.755549 yaitu di X12. Nilai outer loading untuk variabel budaya 
organisasi tertinggi berada di 0.851203 yaitu X23 sedangkan terendah di X22 dengan nilai 0.708141.Nilai outer loading untuk variabel komitmen organisasi tertinggi berada di 0.837280 yaitu Y12 sedangkan terendah di Y11 dengan nilai 0.747631.Untuk variabel kinerja pegawai nilai tertinggi outer loading berada di 0.855340 yaitu Y24 dan Y25, sedangkan terendah berada di 0.780698 yaitu di Y22.

Tabel. 9 . Output Nilai AVE

AVE

AVE

Bud_Org (X2)

Gaya_Kep (X1)

Kinerja Peg (Y2)

Komit_Org (Y1)
0.649112

0.653968

0.686053

0.613759

Sumber : Data primer, diolah

Berdasarkan Tabel 9 di atas tampak bahwa untuk semua nilai AVE di tiap variabel berada di atas angka 0.5.

Tabel. 10. Output Nilai Communality

Communality

\begin{tabular}{cc}
\hline & Communality \\
\hline Bud_Org (X2) & 0.649112 \\
Gaya_Kep (X1) & 0.653968 \\
Kinerja Peg (Y2) & 0.686053 \\
Komit_Org (Y1) & 0.613758 \\
\hline
\end{tabular}

Sumber : Data primer, diolah

Berdasarkan Tabel 10 di atas tampak bahwa untuk semua nilai communality di tiap variabel berada di atas angka 0.5. Hasil ini memberikan arti bahwa data yang digunakan telah memenuhi kriteria uji validitas konvergen karena semua data telah sesuai dengan persyaratan yang ditetapkan yaitu nilai outer loading $>0,7$; AVE $>0,5$; dan Communality $>0,5$.

\section{2) Uji Realibilitas}

Uji reliabilitas bertujuan untuk menguji konsistensi dari butir-butir pertanyaan/pernyataan yang ada dalam kuesioner. Untuk menguji reliabilitas dilakukan dengan menggunakan dua metode, yaitu Cronbach's alpha dan Composite realibility. Rule of thumb nilai Cronbach's alpha atau Composite realibility harus lebih besar dari 0,7 (Hair et al. 2006 dalam Jogiyanto dan Abdillah, 2009). Uji realibilitas terhadap setiap butir-butir pertanyaan/pernyataan dilakukan dengan menjalankan aplikasi smartpls 2.03. Adapun hasil perhitungan cronbach alpha di tampilkan pada Tabel Berikut: 


\section{Tabel. 11. Nilai Cronbach Alpha}

\section{Cronbachs Alpha}

\begin{tabular}{cc}
\hline & Cronbachs Alpha \\
\hline Bud_Org (X2) & 0.823055 \\
Gaya_Kep (X1) & 0.867569 \\
Kinerja Peg (Y2) & 0.908446 \\
Komit_Org (Y1) & 0.789792 \\
\hline
\end{tabular}

Sumber : Data primer, diolah

Berdasarkan Tabel 11 Di atas tampak bahwa nilai cronbachs Alpa dari semua variabel terhadap indikatornya berada di atas dari 0.7. Untuk perhitungan composite Reliability di tampilkan pada Tabel berikut:

Tabel. 12. Hasil perhitungan Composite Reliability

\section{Composite Reliability}

\begin{tabular}{cc}
\hline & Composite Reliability \\
\hline Bud_Org (X2) & 0.880433 \\
Gaya_Kep (X1) & 0.904162 \\
Kinerja Peg (Y2) & 0.929072 \\
Komit_Org (Y1) & 0.863816 \\
\hline
\end{tabular}

Sumber : Data primer, diolah

Berdasarkan Tabel. 10 Di atas tampak bahwa nilai composite reliability dari semua variabel terhadap indikatornya berada di atas dari 0.7 .

3) Uji Hipotesis

Uji hipotesis dalam penelitian ini menggunakan model persamaan struktural (inner model), dimana model struktural diukur menggunakan nilai T-statistic konstruk dependen, nilai beta koefisien path atau T statistic dalam menguji signifikansi hipotesis harus $>1,96$ untuk hipotesis two tailed (Jogiyanto dan Abdillah, 2009). Pengujian model persamaan struktural (inner model) dalam penelitian ini menggunakan aplikasi smartpls 2.03.

Adapun hasil perhitungan uji t statistik di tampilkan pada Tabel berikut:

Tabel. 13. Path Coeficent : Komitmen Organisasi

Laten Value Value t

Gaya Kepemimpinan

0.323

3.924

Budaya Organisasi

0.279

4.006

Sumber : Data primer, diolah.

$$
Y_{1}=0.323 X_{1}+0.279 X_{2}
$$


Tabel. 14. Path Coeficent : KinerjaPegawai

Laten Value Value t

\begin{tabular}{lll}
\hline Gaya Kepemimpinan & 0.305 & 4.250 \\
Budaya Organisasi & 0.457 & 7.155 \\
Komitmen Organisasi & 0.299 & 3.748 \\
\hline
\end{tabular}

Sumber : Data primer, diolah

$$
\mathrm{Y} 2=0.305 \mathrm{X}_{1}+0.457 \mathrm{X}_{2}+0.299 \mathrm{Y}_{1}
$$

Berdasarkan hasil uji t statistik didapatkan nilai t statistik sebagai berikut :

1) Nilai uji t statistik Gaya kepemimpinan terhadap komitmen organisasi adalah sebesar 3.92. Nilai ini lebih besar dari 1,96 sehingga secara statistik terdapat pengaruh signifikan gaya kepemimpinan terhadap komitmen organisasi. Adapun nilai koefisien pengaruh langsung gaya kepemimpinan terhadap komitmen organisasi adalah 0.323. Hasil ini memberikan arti bahwa pengaruh gaya kepemimpinan terhadap komitmen organisasi adalah positif, dimana saat gaya kepemimpinan membaik akan meningkatkan komitmen organisasi pegawai, dengan asumsi pengaruh faktor lain dianggap konstan.

2) Nilai uji t statistik budaya organisasi terhadap komitmen organisasi adalah sebesar 4.00. Nilai ini lebih besar dari 1,96 sehingga secara statistik terdapat pengaruh signifikan budaya organisasi terhadap komitmen organisasi. Adapun nilai koefisien pengaruh langsung budaya organisasi terhadap komitmen organisasi adalah 0.279. Hasil ini memberikan arti bahwa pengaruh budaya organsiasi terhadap komitmen organisasi adalah positif, dimana saat budaya organisasi membaik akan meningkatkan komitmen organisasi pegawai, dengan asumsi pengaruh faktor lain dianggap konstan.

3) Nilai uji t statistik Gaya kepemimpinan terhadap kinerja pegawai adalah sebesar 4.25. Nilai ini lebih besar dari 1,96 sehingga secara statistik terdapat pengaruh signifikan gaya kepemimpinan terhadap kinerja pegawai.

Adapun nilai koefisien pengaruh langsung gaya kepemimpinan terhadap kinerja pegawai adalah 0.305. Hasil ini memberikan arti bahwa pengaruh gaya kepemimpinan terhadap kinerja pegawai adalah positif, dimana saat gaya kepemimpinan membaik akan meningkatkan kinerja pegawai, dengan asumsi pengaruh faktor lain dianggap konstan.

4) Nilai uji t statistik budaya organisasi terhadap kinerja pegawai adalah sebesar 7.15. Nilai ini lebih besar dari 1,96 sehingga secara statistik terdapat pengaruh signifikan budaya organisasi terhadap kinerja pegawai.

Adapun nilai koefisien pengaruh langsung budaya organisasi terhadap kinerja pegawai adalah 0.458 . Hasil ini memberikan arti bahwa pengaruh budaya organsiasi terhadap kinerja pegawai adalah positif, dimana saat budaya organisasi membaik akan meningkatkan kinerja pegawai, dengan asumsi pengaruh faktor lain dianggap konstan.

5) Nilai uji t statistik komitmen organisasi terhadap kinerja pegawai adalah sebesar 3.74. Nilai ini lebih besar dari 1,96 sehingga secara statistik terdapat pengaruh signifikan komitmen organisasi terhadap kinerja pegawai. Adapun nilai koefisien pengaruh langsung komitmen organisasi terhadap kinerja pegawai adalah 0.300. Hasil ini memberikan arti bahwa pengaruh komitmen organisasi terhadap kinerja pegawai adalah positif, dimana saat komitmen organisasi membaik akan meningkatkan kinerja pegawai, dengan asumsi pengaruh faktor lain dianggap konstan. 
Adapun hubungan secara fungsional antar variabel ditampilkan pada Gambar berikut :

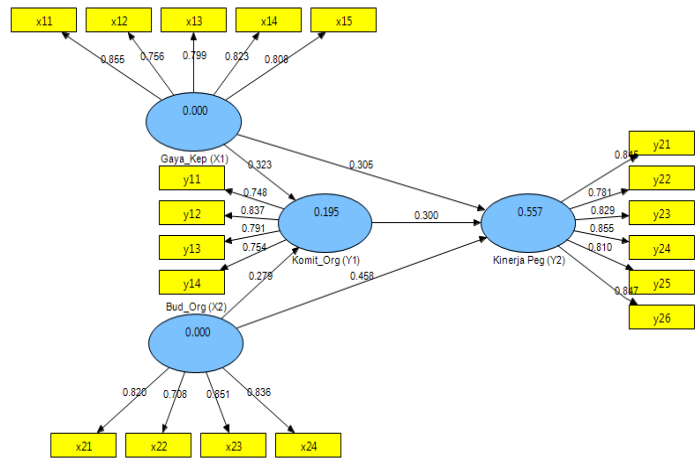

\section{Gambar 2. Hubungan Antar variabel dalam bentuk Skema}

Berdasarkan gambar diatas,maka dapat dijelaskan pengaruh tidak lansung antara variabel. Khusus untuk pengaruh tidak langsung variabel gaya kepemimpinan (X1) terhadap variabel kinerja pegawai (Y2) melalui variabel komitmen organisasi (Y1)nilai koefisiennya sebesar 0.323 × $0.300=0.097$. sedangkan pengaruh tidak langsung untuk variabel budaya orgaisasi (X2) terhadap variabel kinerja pegawai (Y2) melalui variabel komitmen organisasi (Y1) nilai koefisiennya sebesar $0.278 \times 0.300=0,458$.

Sesuai dengan kajian teoritis dan hasil pengujian hipotesis sebelumnya, dikatakan bahwa gaya kepemimpinan dan budaya organisasi akan memiliki efek langsung maupun tidak langsung terhadap kinerja pegawai. Pengaruh tidak langsung dari variabel tersebut adalah dengan terlebih dahulu melewati variabel komitmen organisasi, yang selanjutnya berpengaruh terhadap kinerja pegawai.

Hasil pengujian pengaruhantara varibel gaya kepemimpinan terhadap kinerja pegawai melalui komitmen organisasi dan variabel budaya organisasi terhadap kinerja pegawai melalui komitmen organisasi dapat diringkas sebagai berikut :

\section{Tabel. 14 Pengaruh Tidak Langsung}

Keterangan

Gaya Kepemimpinan

Budaya Organisasi

\section{Pengaruh}

Tidak Langsung

(b)

$0.323 \times 0.300=0.097$

$0.279 \times 0.300=0.084$

Sumber : data primer diloah

Adapun nilai total efek dapat dijelaskan sebagaimana tabel dibawah ini : 
Tabel. 15. Nilai Total Efek

\begin{tabular}{lccc}
\hline Keterangan & $\begin{array}{c}\text { Pengaruh } \\
\text { Langsung } \\
\text { (a) }\end{array}$ & $\begin{array}{c}\text { Pengaruh } \\
\text { Tidak Langsung } \\
\text { (b) }\end{array}$ & $\begin{array}{c}\text { Total } \\
(\mathbf{a}+\mathbf{b})\end{array}$ \\
\hline Gaya Kepemimpinan & & & 0.402 \\
Budaya Organisasi & 0.305 & $0.323 \times 0.300=0.097$ & 0.542 \\
\end{tabular}

Sumber : data primer diolah

Berdasarkan tabel 14 dan tabel 15, maka dapat dijelaskan pengaruh tidak langsung untuk setiap varibael sebagai berikut :

a. Pengaruh gaya kepemimpinan terhadap kinerja pegawai melalui komitmen organisasi.

Pengaruh tidak langsung gaya kepemimpinan terhadap kinerja pegawai melalui komitmen organisasi dengan nilai sebesar 0,097. Implikasi temuan ini adalah bahwa komitmen organisasi tidak menjadi variabel antara yang tidak mendukung dalam hubungan gaya kepemimpinan dengan kinerja pegawai. Sementara nilai pengaruh langsung gaya kepemimpinan terhadap kinerja pegawai sebesar o,305 signifikan, artinya semakin baik gaya kepemimpinan maka semakin meningkatnya kinerja pegawai. Dengan demikian nilai pengaruh langsung gaya kepemimpinan terhadap kinerja pegawai lebih besar dibandingkan pengaruh tidak langsung gaya kepemimpinan terhadap kinerja pegawai melalui komitmen organisasi.

b. Pengaruh budaya organisasi terhadap kinerja pegawai melalui komitmen organisasi.

Pengaruh tidak langsung budaya organisasi terhadap kinerja pegawai melalui komitmen organisasi dengan nilai sebesar 0,084. Implikasi temuan ini adalah bahwa komitmen organisasi tidak menjadi variabel antara yang tidak mendukung dalam hubungan budaya organisasi dengan kinerja pegawai. Sementara nilai pengaruh langsung gaya kepemimpinan terhadap kinerja pegawai sebesar 0,458 signifikan, artinya semakin baik budaya organisasi maka semakin meningkatnya kinerja pegawai. Dengan demikian nilai pengaruh langsung budaya organisasi terhadap kinerja pegawai lebih besar dibandingkan pengaruh tidak langsung budaya organisasi terhadap kinerja pegawai melalui komitmen organisasi.

\section{Pengaruh Gaya kepemimpinan terhadap komitmen organisasi}

Pemimpin yang efektif dalam menerapkan gaya tertentu dalam kepemimpinannya terlebih dahulu harus memahami siapa bawahan yang dipimpinnya, mengerti kekuatan dan kelemahan bawahannya, dan mengerti bagaimana cara memanfaatkan kekuatan bawahan untuk mengimbangi kelemahan yang mereka miliki. Brown 2003, dalam Suhana 2007 menguji pengaruh perilaku kepemimpinan yang berorientasi pada hubungan dan tugas terhadap komitmen organisasi. Temuannya menunjukkan bahwa perilaku kepemimpinan yang berorientasi pada hubungan yang meliputi membangun kepercayaan, memberikan inspirasi, visi, mendorong kreativitas dan menekankan pengembangan berpengaruh secara positif pada komitmen afektif karyawan. Sementara perilaku kepemimpinan yang berorientasi pada tugas juga berpengaruh terhadap komitmen afektif karyawan, meski tingkat pengaruhnya lebih rendah.

Penelitian yang dilakukan Chen (2004) menunjukkan bahwa budaya organisasi dan gaya kepemimpinan berpengaruh signifikan positif terhadap komitmen organisasi, kepuasan kerja dan kinerja karyawan. Selain itu Perryer dan Jordan (2005) meneliti dasar hubungan antara komitmen organisasi dan gaya kepemimpinan dilihat dari 
gaya mendukung (support) dan gaya memadamkan (extinct) pada organisasi Pemerintah Federal Australia. Hasil penelitiannya menemukan bahwa baik gaya mendukung dan gaya memadamkan yang dimiliki seorang pemimpin mempengaruhi komitmen berorganisasi, dimana terjadi sebuah peningkatan dalam gaya mendukung yang dimiliki seorang pemimpin bersamaan dengan penurunan dalam gaya pemimpin yang cenderung memadamkan akan meningkatkan komitmen. Sedangkan Bourantas dan Papalexandris (1993) dalam penelitiannya pada organisasi publik dan swasta di Yunani menemukan perbedaan yang signifikan pada pengaruh kepemimpinan terhadap kepuasan dan komitmen karyawan dimana pada organisasi publik kurang signifikan dibandingkan dengan organisasi swasta. Hal tersebut didukung dengan fakta bahwa karena peraturan upah mereka, penarikan, pemilihan, pelatihan, dan kriteria serta prosedur kenaikan pangkat, organisasi publik di Yunani kurang efektif dari pada organisasi swasta dalam menjaga kopetensi pemimpin. Selain itu, organisasi swasta lebih bersaing dalam pasar buruh untuk menarik pemimpin yang tersedia lebih dapat bersaing.

Hasil penelitian ini sejalan dengan penelitian sebelumnya yang dilakukan oleh Durrotun Nafisah (2005), Adri Agustiningrum (2012), dan Budi Santosa(2012) dimana kepemimpinan berpengaruh positif dan signifikan terhadap kinerja karyawan.

Implikasi teoritis yang disarankan adalah jika suatu instansi ingin meningkatkan komitmen organisasinya maka sedapat mungkin memperbaiki model gaya kepemimpinannya.

\section{Pengaruh Budaya Organisasi Terhadap Komitmen Organisasi}

Berdasarkan hasil perhitungan statistic terdapat pengaruh signifikan budaya organisasi terhadap komitmen organisasi. Artinya bahwa budaya organisasi membaik akan meningkatkan komitmen organisasi pegawai baik dari aspek keberhasilan organisasi maupun kemajuan yang berkelanjutan.

Anggota organisasi dalam bekerja saling mendukung dan terbuka serta bersikap hangat (ramah) dalam pergaulan mengindikasi bahwa untuk menciptakan suasana kerja yang kondusif dan berkualitas maka diharapkan anggota organisasi dalam bekerja harus saling mendukung dan terbuka serta bersikap ramah antara anggota organisasi (pegawai).

Anggota organisasi mencurahkan seluruh kemampuannya untuk bekerja temuan ini mengindikasi bahwa berhasil dan tidaknya suatu pekerjaan ditentukan oleh bagaimana para pegawai dapat menghargai tanggung jawab pekerjaan yang diberikan sehingga dapat mencurahkan pikiran dan tenaga untuk menyelesaikan pekerjaan dimaksud sesuai target.

Temuan penelitian juga bahwa anggota organisasi mengorganisasikan pekerjaannya bersama, artinya para pegawai dituntut untuk dapat mengorganisir pekerjaannya secara bersama-sama dengan baik sehingga melalui kerjasama yang dibangun akan menghasilkan pekerjaan yang berkualitas.

Kaitannya dengan pengaruh indikator diatas terhadap komitmen organisasi, maka akan berdampak terhadap kesediaan pegawai menerima semua macam penugasan agar tetap bekerja dengan organisasi sebagai cerminan komitmen mereka dengan pekerjaannya.

Budaya organisasi adalah suatu sistem nilai yang diperoleh dan dikembangkan oleh organisasi dan pola kebiasaan dan falsafah dasar pendirinya, yang terbentuk menjadi aturan yang digunakan sebagai pedoman dalam berfikir dan bertindak dalam mencapai tujuan organisasi. Budaya kuat merupakan budaya dimana nilai inti organisasi itu dipegang secara mendalam dan dianut bersama secara meluas (Robbin, 2006). Selain itu Robbin (2006) berpendapat budaya organisasi adalah suatu sistem makna bersama yang dianut oleh anggota-anggota yang membedakan organisasi itu dari organisasi-organisasi lain. Sedangkan menurut Furnham dan Gunter (1993, dalam Sunarto, 2005) budaya organisasi sebagai keyakinan, sikap dan nilai yang umumnya dimiliki, yang timbul dalam suatu organisasi dikemukakan dengan lebih sederhana, budaya adalah "cara kami melakukan sesuatu disekitar sini". Dari berbagai studi tentang budaya organisasi berpengaruh dalam aspek organisasional seperti: peningkatan 
komitmen organisasi. McKinnon et.al (2001). Terdapat tujuh karakteristik primer yang merupakan hakikat dari budaya organisasi menurut Robbin (2006), yaitu:

1. Inovasi dan mengambil resiko, artinya sejauh mana para karyawan didorong untuk bersikap inovatif dan mengambil resiko.

2. Perhatian terhadap detail,artinya sejauh mana karyawan diharapkan memperlihatkan kecermatan, analisis dan perhatian terhadap detail.

3. Orientasi hasil,artinya sejauh mana para manajemen memusatkan perhatian pada hasil bukannya pada tehnik dan proses-proses yang digunakan untuk mencapi hasil-hasil itu.

4. Orientasi orang,artinya sejauh mana keputusan-keputusan manajemen memperhitungkan pengaruh hasil-hasil terhadap manusia didalam organisasi.

5. Orientasi tim, artinya sejauh mana kegiatan kerja diorganisasikan berdasarkan tim, bukan berdasarkan individu.

6. Keagresifan, artinya sejauh mana orang bersikap agresif dan bersaing dan bukannya santai-santai.

7. Kemantapan, artinya sejauh mana kegiatan Organisasi menekankan dipertahankannya status quo bukannya pertumbuhan.

Moon (2000) dalam penelitiannya menunjukkan bahwa budaya Organisasi yang diukur melalui kejelasan tujuan organisasi dan otonomi pekerjaan mempunyai pengaruh yang signifikan positif terhadap komitmen organisasi baik pada perusahaan swasta maupun perusahaan pemerintah.

Secarateoritis Michael Ritchie (2000) meneliti pengaruh proses internalisasi budaya organisasi terhadap kinerja karyawan bank. Hasil penelitian tersebut menyimpulkan bahwa budaya organisasi mempunyai pengaruh positif terhadap sikap karyawannya, yang mana jika budaya organisasi kuat akan menciptakan perasaan memiliki dan meningkatkan kepuasandan komitmen kerja.

Hasil ini sejalan dengan teori yang dikemukakan oleh guru besar university of Colorado di Denver, M. Jae Moon dalam Wirawan (2007) meneliti hubungan antara komitmen organisasi, budaya organisasi dan sejumlah variable lainnya. Penelitian lainnya menunjukkan bahwa tujuan organisasi mengarah pada kinerja dan komitmen organisasi yang tinggi. Ketika anggota menerima dan menilai tujuan organisasi, komitmen organisasinya juga meningkat.

Berdasarkan fakta tersebut Moon dalam Wirawan (2007) juga mengajukan hipotesis bahwa derajat kejelasan tujuan dalam organisasi secara positif berasosiasi dengan komitmen organisasi dan derajat ekonomi pekerjaan secara positif berasosiasi dengan komitmen organisasi.

Penemuan ini sesuai Steer dan Porter (1983), suatu bentuk komitmen kerja yang muncul bukan hanyabersifat loyalitas yang pasif tetapi juga melibatkan hubungan yang aktif dengan organisasi kerja yang memiliki tujuan memberikan segala usaha demi keberhasilan organisasi yang bersangkulan. Penelitian lain yang mendukung yaitu Ogbor (1999) menyatakan bahwa budaya organisasi yang memberi rasa nyaman dalam bekerjadan kepercayaan yang tinggi akan mendorong peningkatan perilaku kerja melalui tingginya kohesitas anta rindividu dan komitrnen dari warga organisasi untuk melakukan yang terbaik bagi kepentingan organisasi.

Implikasi teoritis yang disarankan adalah jika suatu instansi ingin meningkatkan komitmen organisasinya maka sedapat mungkin memperbaiki budaya organisasinya.

\section{Pengaruh Gaya KepemimpinanTerhadapKinerjaPegawai}

Berdasarkan hasil perhitungan statistik diketahui bahwa pengaruh gaya kepemimpinan terhadap kinerja pegawai adalah positif dan signifikan, sehingga saat gaya kepemimpinan membaik akan meningkatkan kinerja pegawai.. Artinya, semakin baik pemimpin dalam mengarahkan dan mempengaruhi pekerja dalam pekerjaannya, maka semakin baik pula kinerja pegawainya.

Pemimpin yang menuntut bawahannya memprioritaskan pelaksanaan tugas dari pada urusan yang lain, menunjukkan bahwa pemimpin ingin agar tugas-tugas pekerjaan harus diutamakan dan menjadi skala prioritas oleh 
bawahannya sehingga pekerjaan dapat terselesaikan dengan baik dan bawahan dapat melaksanakan urusan-urusan yang lain.

Pemimpin bergaul secara informal dengan bawahan mengindikasikan bahwa dalam melaksanakan pekerjaan pemimpin selalu membuka diri dan tidak membatasi ruang komunikasi serta pergaulan dengan bawahan. Hal ini dimaksudkan agar bawahan tidak kaku dalam melaksanakan pekerjaanya terlebih dalam membangun hubungan dengan pemimpin.

Pemimpin sering memotivasi anak buah mengindikasi bahwa dalam mendistrubusikan tanggung jawab pekerjaan tidak hanya dilakukan secara normatif tetapi pemimpin terus memberikan motivasi kepada bawahan untuk fokus dan bertanggung jawab dalam menyelesaikan pekerjaannya.

Temuan penelitian juga bahwa pemimpin mengharapkan bawahan untuk mematuhi peraturan yang berkaitan dengan pekerjaan mereka serta pemimpin memuji dan menghargai mereka yang bekerja keras artinya pemimpin menginginkan supaya seluruh pegawai mematuhi peraturan serta berdisplin tinggi dalam melaksanakan tugas dan tanggung jawab pekerjaannya dengan demikian pemimpin akan memberikan pujian dan penghargaan kepada pegawai yang memiliki prestasi dan dedikasi atas pekerjaan mereka.

Kaitannya dengan pengaruh indikator diatas terhadap kinerja pegawai, maka akan berdampak terhadap pegawai dapat melaksanakan pekerjaan dengan tepat waktu sebagai suatu usaha untuk menghasilkan pekerjaan yang berkualitas dan bermanfaat.

Kepemimpinan pada dasarnya adalah proses mempengaruhi orang lain. Selain itu kepemimpinan juga berarti kemampuan untuk mempengaruhi, menggerakkan, dan mengarahkan suatu tindakan pada diri seseorang atau sekelompok orang untuk tujuan tertentu. Dalam upaya mempengaruhi tersebut seorang pemimpin menerapkan gaya yang berbeda-beda dalam setiap situasi. Dimana menurut Stoner et. al (1996) gaya kepemimpinan (leadership styles) merupakan berbagai pola tingkah laku yang disukai oleh pemimpin dalam proses mengarahkan dan mempengaruhi pekerja. Dari pengertian tersebut terungkap bahwa apa yang dilakukan oleh atasan mempunyai pengaruh terhadap bawahan, yang dapatmembangkitkan semangat dan kegairahan kerja maupun sebaliknya. Ogbonna dan Harris (2000) dalam penelitiannya menunjukkan bahwa kepemimpinan yang diperankan dengan baik oleh seorang pemimpin mampu memotivasi karyawan untuk bekerja lebih baik, hal ini akan membuat karyawan lebih hati-hati berusaha mencapai target yang diharapkan perusahaan, hal tersebut berdampak pada kinerjanya.

Hasil penelitian Ogbonna dan Harris (2000) menunjukkan bahwa budaya organisasi mampu memoderasi pengaruh gaya kepemimpinan terhadap kepuasan kerja yang berdampak pada peningkatan kinerja karyawan. Chen (2004) dalam penelitiannya menguji pengaruh antara budaya organisasi dan peran kepemimpinan terhadap komitmen organisasi, kepuasan kerja dan kinerja karyawan pada perusahaan industri kecil dan menengah di Taiwan. Fiedler (1996, dalam Ogbonna dan Harris, 2000) membuktikan pentingnya efektifitas kepemimpinan dengan argumentasinya bahwa efektivitas seorang pemimpin merupakan determinan utama keberhasilan atau kegagalan kelompok, organisasi atau bahkan negara.

Implikasi teoritis yang disarankan adalah jika suatu instansi ingin meningkatkan kinerja pegawainya maka sedapat mungkin memperbaiki gayakepemimpinannya.

\section{Pengaruh Budaya Organisasi terhadap Kinerja Pegawai}

Budaya organisasi berpengaruh positif dan signifikan terhadap kinerja pegawai.Ini berarti bahwa saat budaya organisasi membaik akan meningkatkan kinerja pegawai. Anggota organisasi dalam bekerja saling mendukung dan terbuka serta bersikap hangat (ramah) dalam pergaulan mengindikasi bahwa untuk menciptakan suasana kerja yang kondusif dan berkualitas maka diharapkan anggota organisasi dalam bekerja harus saling mendukung dan terbuka serta bersikap ramah antara anggota organisasi (pegawai).

Anggota organisasi mencurahkan seluruh kemampuannya untuk bekerja temuan ini mengindikasi bahwa berhasil dan tidaknya suatu pekerjaan ditentukan oleh bagaimana para pegawai dapat menghargai tanggung jawab 
pekerjaan yang diberikan sehingga dapat mencurahkan pikiran dan tenaga untuk menyelesaikan pekerjaan dimaksud sesuai target.

Temuan penelitian juga bahwa anggota organisasi mengorganisasikan pekerjaannya bersama, artinya para pegawai dituntut untuk dapat mengorganisir pekerjaannya secara bersama-sama dengan baik sehingga melalui kerjasama yang dibangun akan menghasilkan pekerjaan yang berkualitas.

Kaitannya dengan pengaruh indikator diatas terhadap kinerja pegawai, maka akan berdampak terhadap pegawai untuk dapat melaksanakan pekerjaan dengan tepat waktu sebagai cerminan untuk meningkatkan kinerja mereka.

Pada dasarnya manusia atau seseorang yang berada dalam kehidupan organisasi berusaha untuk menentukan dan membentuk sesuatu yang dapat mengakomodasikan kepentingan semua pihak, agar dapat menjalankan aktivitasnya tidak berbenturan dengan berbagai sikap dan perilaku dari masing-masing individu. Sesuatu yang dimaksud adalah budaya dimana individu berada, seperti nilai, keyakinan, anggapan, harapan dan sebagainya.

Kreitner dan Kinicki (2005) mengemukakan bahwa budaya organisasi adalah nilai keyakinan bersama yang mendasari identitas perusahaan. Mengingat budaya organisasi merupakan suatu kesepakatan bersama para anggota dalam Organisasiatau perusahaan sehingga mempermudah lahirnya kesepakatan yang lebih luas untuk kepentingan perorangan. Keutamaan budaya organisasi merupakan pengendali dan arah dalam membentuk sikap dan perilaku manusia yang melibatkan diri dalam suatu kegiatan organisasi, sebagaimana Deal dan Kennedy (1982) dan Ouchi (1981) dalam McKinnon et.al (2003) menyatakan bahwa budaya organisasi mempengaruhi produktivitas, kinerja, komitmen, kepercayaan diri, dan perilaku etis. Penelitian yang dilakukan Chen (2004) menunjukkan bahwa budaya organisasi dan gaya kepemimpinan berpengaruh signifikan positif terhadap komitmen organisasi, kepuasan kerja dan kinerja karyawan. Dukungan tinggi yang ditunjukkan oleh pemimpin perusahaan mampu memberikan motivasi yang tinggi dari karyawan untuk bekerja lebih baik dan mencapai target.

Implikasi teoritis yang disarankan adalah jika suatu instansi ingin meningkatkan kinerja pegawainya dapat dilakukan dengan memperbaik ibudayaorganisasinya.

\section{Pengaruh Komitmen Organisasi terhadap Kinerja Pegawai}

Dari hasil perhitungan statistik diketahui bahwa komitmen organisasi berpengaruh positif dan signifikan terhadap kinerja pegawai. Ini berarti bahwa saat komitmen organisasi membaik akan meningkatkan kinerjapegawainya menunjukan bahwa pegawai memiliki komitmen yang tinggi akan meningkatkan kinerjanya

Pegawai bersedia menerima semua macam penugasan agar tetap bekerja dengan organisasi. Artinya apapun pekerjaan yang diberikan maka sebagai anggota organisasi (pegawai) tetap melaksanakan pekerjaannya dengan sungguh-sungguh tanpa melihat besar atau kecilnya pekerjaan. Dengan adanya komitmen tersebut maka akan membentuk karakter pegawai yang mencintai dan setia dengan pekerjaanya.

Temuan penelitian juga bahwa organisasi benar-benar memberi inspirasi yang bagus untuk berprestasi, artinya dengan rasa kecintaan terhadap organisasinya, setiap pegawai dengan bangga mempublikasikan kepada orang lain bahwa iklim kerja di organisasinya memberikan ruang yang menyenangkan sehingga menghasilkan pegawai yang berprestasi.

Merasa bangga menjadi bagian dari organisasi mengindikasikan bahwa seorang pegawai yang diberikan kesempatan untuk menjadi bagian dari suatu organisasi, dan ketika pekerjaan diorganisasikan sesuai dengan kompetensi dan kualifikasi dari pegawai tersebut maka dengan sendirinya pegawai tersebut akan merasa bangga dan menghasilkan kinerja yang baik.

Kaitannya dengan pengaruh indikator diatas terhadap kinerja pegawai, maka akan berdampak terhadap pegawai untuk dapat melaksanakan pekerjaan dengan tepat waktu sebagai cerminan untuk meningkatkan kinerja mereka. 
Menurut Morrison (1994, dalam Sitty Yuwalliantin 2006) komitmen dianggap penting bagi organisasi karena : (1) Pengaruhnya pada turn over. (2) Hubungannya dengan kinerja yang mengasumsikan bahwa individu yag memiliki komitmen cenderung mengembangkan upaya yang lebih besar pada pekerjaaan. Dalam penelitian yang dilakukan Benkhoff (1997), komitmen organisasi memegang peranan penting bagi peningkatan kinerja yang baik dan pengabaian terhadap komitmen pada organisasi akan menimbulkan suatu kerugian.

Mowday, Steers dan, Potter (1979, dalam Bourantas dan Papalexandris, 1993) mendefinisikan komitmen organisasi sebagai kekuatan relatif dalam pengidentifikasian keterlibatan dirinya dengan organisasi. Mereka menyatakan bahwa komitmen organisasi mempunyai tiga komponen utama, yaitu:

a. Keyakinan yang kuat, dan penerimaan nilai dan tujuan organisasi.

b. Keinginan untuk berusaha keras yang dapat dipertanggungjawabkan atas nama organisasi.

c. Keinginan kuat untuk tetap sebagai anggota organisasi.

Dalam menghitung variabel kuesioner Mowday, Steers dan Potter (1979, dalam Perryer dan Jordan, 2005) terdiri dari lima belas item, jawaban diberikan dengan skala 7 poin $(1=$ sangat tidak setuju dan $7=$ sangat setuju $)$ dan merupakan instrument yang paling sering digunakan untuk pengukuran komitmen organisasi. Sedangkan studi Allen dan Meyer (1990) membedakan komitmen organisasi atas tiga komponen, yaitu affektive, normative dan continuance.

a. Komponen affektive keterikatan emosional karyawan, identifikasi dan keterlibatan karyawan di dalam suatu organisasi.

b. Komponen normative merupakan perasaan-perasaan karyawan tentang kewajiban yang harus ia berikan kepada organisasi.

c. Komponen continuance/kelanjutan berarti komponen berdasarkan persepsi karyawan tentang kerugian yang akan dihadapi jika ia meninggalkan organisasi.

Secara umum, komitmen organisasi dianggap sebagai ukuran yang penting dari keefektifan organisasi Steers (1975, dalam Suhana, 2006). McNeese-Smith (1996) dan Sulaiman (2002) dalam penelitiannya menyatakan komitmen organisasi berhubungan positif dengan kinerja karyawan. Implikasi teoritis yang disarankan adalah jika suatu instansi ingin meningkatkan kinerja pengawainya maka sedapat mungkin komitmen organisasinya ditingkatkan.

\section{Pengaruh Gaya Kepemimpinan Terhadap Kinerja Pegawai Melalui Komitmen Organisasi.}

Hasil perhitungan statistik menunjukan bahwa gaya kepemimpinan berpengaruh positif dan signifikan terhadap kinerja pegawai. Hal ini menunjukan bahwa gaya kepemimpinan yang diterapkan sudah baik sehinggadapat meningkatkan kinerja pegawai. Bahwa dengan gaya kepemimpinan yang ada saat ini, diharapkan melalui komitmen organisasi yang sudah terbentuk dan dimiliki oleh para pegawai, maka akan memotivasi pegawai dalam meningkatkan kinerjanya. Namun demikian hasil perhitungan tidak langsung menunjukan bahwa gaya kepemimpinan akan lebih bagus meningkatkan kinerja pegawai secara langsung meski tanpa didukung adanya komitmen organisasi yang tinggi. Hal ini mendukung penelitian Humphreys (2002) yang mengatakan bahwa kinerja karyawan sangatdipengaruhi oleh gaya kepemimpinan. Variabel gaya kepemimpinan menunjukkan pengaruh positif terhadap kinerja pegawai. Bahwa walaupun pengaruh tidak langsung nilainya sangat kecil jika dibandingkan dengan pengaruh tidak langsung, tetapi dalam analisis jalur tetap memberikan pengaruh yang positif karena memiliki total efek yang cukup besar.

\section{Pengaruh Budaya OrganisasiTerhadap Kinerja Pegawai Melalui Komitmen Organisasi.}

Berdasarkan hasil perhitungan statistik menunjukan bahwa budaya organisasi berpengaruh positif dan signifikan terhadap kinerja pegawai. Hal ini menunjukan bahwa pegawai sudah memiliki budaya organisasi yang baik dan akan mendorong para pegawai untuk terus meningkatkan kinerjanya di masa yang akan datang. Bahwa dengan budaya Organisasiyang ada saat ini, diharapkan melalui komitmen organisasiyang sudah terbentuk dan dimiliki oleh para pegawai, maka akan memotivasi pegawai dalam meningkatkan kinerjanya. Namun demikian 
hasil perhitungan tidak langsung menunjukan bahwa budaya organisasi akan lebih bagus meningkatkan kinerja pegawai secara langsung meski tanpa didukung adanya komitmen organisasi yang tinggi. Hal ini mendukung penelitian Chatman Jennifer dan Bersade (1997) yang mengatakan bahwa kinerja karyawan sangat dipengaruhi oleh budaya organisasi.

Variabel budaya organisasi menunjukkan pengaruh positif terhadap kinerja karyawan. Bahwa walaupun pengaruh tidak langsung nilainya sangat kecil jika dibandingkan dengan pengaruh tidak langsung, tetapi dalam analisis jalur tetap memberikan pengaruh yang positif karena memiliki total efek yang cukup besar.

\section{PENUTUP}

\section{Kesimpulan}

Berdasarkan hasil penelitian maka dapat disimpulkan sebagai berikut :

1. Bahwa terdapat pengaruh yang positif dan signifikan antara variabel Gaya kepemimpinan (X1) terhadap komitmen organisasi (Y1). Artinya bahwa baik semakin tinggi gaya kepemimpinan yang diterapkan akan diikuti oleh tingginya komitmen organisasi pegawai. Sehingga saat komitmen organisasi ingin di tingkatkan maka gaya kepemimpinan sedapat mungkin diperbaiki. Adapun gaya kepemimpinan yang menjadi perhatian pegawai Badan Pengembangan Sumberdaya Manusia Provinsi Maluku adalah mengharapkan agar Pimpinan menuntut bawahan untuk memprioritaskan pelaksanaan tugas dari pada urusan lain.

2. Terdapat pengaruh yang positif dan signifikan antara variabel Budaya organisasi (X2) terhadap komitmen organisasi (Y1). Hal ini mengindikasikan bahwa semakin tinggi budaya organisasi, akan diikuti semakin tinggi komitmen organisasi pegawai. Sehingga saat komitmen organisasiingin di tingkatkan maka budaya organisasi sedapat mungkin diperbaiki. Adapun budaya organisasi yang menjadi perhatianpegawai Badan Pengembangan Sumberdaya Manusia Provinsi Maluku adalah menginginkan anggota organisasi dalam bekerja saling mendukung dan terbuka begitupula dengan anggotaorganisasi bersikapramahdalampergaulan.

3. Terdapat pengaruh yang positif dan signifikan antara variabel Gaya kepemimpinan (X1) terhadap kinerja pegawai (Y2).Artinya bahwa semakin tinggi gaya kepemimpinan yang diterapkan akan diikuti dengan tingginya kinerja pegawai. Sehingga saat kinerja pegawai ingin di tingkatkan maka gaya kepemimpinan sedapat mungkin diperbaiki.

4. Bahwa variabel Budaya organisasi (X2) berpengaruh positif dan signifikan terhadap kinerja pegawai (Y2). Artinya bahwa semakin baik budaya organisasi akan diikuti dengan semakin tinggi kinerja pegawai. Sehingga saat kinerja pegawai ingin di tingkatkan maka budaya organisasi sedapatmungkin diperbaiki.

5. Bahwa variabel Komitmen organisasi (Y1) berpengaruh positif dan signifikan terhadap kinerja pegawai (Y2), hal ini berarti bahwa semakin tinggi komitmen organisasi maka semakin tinggi kinerja pegawai. Sehingga saat kinerja pegawai ingin ditingkatkan maka komitmen organisasi sedapat mungkin ditingkatkan. Adapun komitmen organisasi yang menjadi perhatian pegawai Badan Pengembangan Sumberdaya Manusia Provinsi Maluku adalah membanggakan kepada orang lain bahwa organisasi tempat bekerja adalah tempat yang bagus. Hasil ini menunjukan bahwa pegawai pada instansi tersebut sangat loyal dan bangga terhadap tempat dimana ia bekerja sehingga keberadaannya ingin diketahui oleh orang lain.

6. Hasil perhitungan statistik menunjukan bahwa gaya kepemimpinan (X1) berpengaruh positif dan signifikan terhadap kinerja pegawai (Y2). Hal ini menunjukan bahwa gaya kepemimpinan yang diterapkan sudah baik sehingga dapat meningkatkan kinerja pegawai. Namun demikian hasil perhitungan tidak langsung menunjukan bahwa gaya kepemimpinan akan lebih bagus meningkatkan kinerja pegawai secara langsung meski tanpa didukung adanya komitmen organisasi yang tinggi.

7. Berdasarkan hasil perhitungan statistik menunjukan bahwa budaya organisasi (X2) berpengaruh positif dan signifikan terhadap kinerja pegawai (Y2). Hal ini menunjukan bahwa pegawai sudah memiliki budaya organisasi yang baik dan akan mendorong para pegawai untuk terus meningkatkan kinerjanya di masa yang akan datangNamun demikian hasil perhitungan tidak langsung menunjukan bahwa budaya organisasi akan lebih bagus meningkatkan kinerja pegawai secara langsung meski tanpa didukung adanya komitmen organisasi yang tinggi. 


\section{Saran}

Berdasarkan hasil penelitian ini, maka penulis ingin memberikan saran sebagai berikut :

1. Untuk mendapatkan perbaikan kinerja pegawai secara berkesinambungan diharapkan pegawai di lingkungan Badan Pengembangan Sumberdaya Manusia Provinsi Maluku memperbaiki model gaya kepemimpinannya dan budayaorganisasinya sehingga komitmen organisasinya meningkat dan berdampak pada kinerja pegawai.

2. Terdapat beberapa variabel lain yang secara teoritis dapat mempengaruhi peningkatan kinerja pegawai diluar dari model yang diajukan diantaranya lingkungan kerja, semangat kerja, kompetensi dan lain-lain sehinggadiharapkan untuk peneliti selanjutnya untuk menggunakan variable tersebut untuk lebih memperkaya khasanah penelitian manajemen sumberdaya manusia.

\section{DAFTAR PUSTAKA}

Cokroaminoto, (2007). Membangun Kinerja Memaknai Kinerja Karyaw. cokroaminoto.wordpress.com/20070523/memaknaikinerja-karyawan.

Dewi, A. R. S., dan Hasniaty (2017). Pengaruh Gaya Kepemimpinan, Budaya Organisasi dan Komitmen Organisasi Terhadap Kinerja Pegawai Dinas Pertanian Kabupaten Mamuju. Jurnal Bisnis Manajemen dan Informatika, Vol. 14. No. 2. Pp 92-102.

Gibson, J., Ivancevich, J., Donelly Jr., J. \& Robert, K. (2006). Organizations (Behavior, Structure, Processes. Twelfth Edition, McGrow Hill.

George, J. and Gareth, R. J. (2012). Understanding and Managing Organizational Behavior. Pearson Education, Inc, New Jersey.

Utami, H. (2006). Pengaruh Budaya Organisasi, Gaya Kepemimpinan Dan Komitmen Organisasi Terhadap Kinerja Pegawai. Ekombis Review, Jurnal Unived, Hal. 206.

Keputusan Menteri Pendayagunaan Aparatur RI Nomor: 25/KEP/M.PAN/04/2002. Tentang Pedoman Pengembangan Budaya Kerja Aparatur Negara.

Keban, Y. T. (2008). Enam Dimensi Strategis Administrasi Publik: Konsep, Teori, Dan Isu. Gava Media, Yogyakarta.

Kartono, K. (2008). Pemimpin dan Kepemimpinan. Jakarta: Raja Grafindo Persada.

Kreitner, R., dan Kinicki, A. (2005). Perilaku Organisasi, Buku 1, Edisi Kelima, Salemba Empat, Jakarta.

Kreitner, R., dan Kinicki, A. (2011). Perilaku Organisasi. Jakarta: Salemba Empat.

Mathis, R. L. dan Jackson, J. H. (2001). Manajemen Sumberdaya Manusia, Buku 1, Salemba Empat Jakarta.

Mahsun. M. (2006). Pengukuran Kinerja Sector Public. BPFE: Yogyakarta.

Menon, M. E. (2002). Perceptions of Pre-Service and In-Service Teachers Regarding the Effectiveness of Elementary School Leadership in Cyprus, The International Journal of Educational Management, 16 February, 91-97. 
Miftah, T. (1983). Perilaku Organisasi; Konsep Dasar dan Aplikasinya, Edisi 1, PT RajaGrafindo Persada, Jakarta.

Peraturan Pemerintah Nomor 10 Tahun 1979 tentang Pelaksanaan Pekerjaan Pegawai Negeri Sipil.

Prawirosentono, S. (2000). Kebijakan Kinerja Karyawan, BPFE, Yogyakarta.

Robbins, S. P. (2006). Perilaku Organisasi, Edisi kesepuluh, PT Indeks Jakarta.

Robbins, S. P. dan Coulter, M. (2010). Manajemen, diterjemahkan oleh Bob Sabran, Wibi Hardani. Erlangga: Jakarta.

Robbins, S. P. dan Timothy A. J. (2012). Perilaku Organisasi. Salemba Empat. Jakarta.

Schein, E. H. (2004). Organizational Culture and Leadership, Third Edition, Jossey -Bass Publishers, San Francisco.

Siagian, S. P. (2002). Kiat Meningatkan Produktivitas Kerja. PT. RINEKA CIPTA, Jakarta.

Sitty, Y. (2006). Pengaruh Budaya Organisasi, Motivasi, dan Komitmen Terhadap Kinerja Serta Pengaruhnya Terhadap Keunggulan Kompetitif Dosen Unissula Semarang. EKOBIS Vol. 7 No. 2, Juni, h. 241-256.

Sopiah. (2008). Perilaku Organisasi, Andi, Yogyakarta.

Stoner, J. A.F., Freeman, R. E., Gilbert Jr., D. R. (1996). Manajemen, Jilid I, PT Bhuana Ilmu Populer.

Tambengi, K. F. S., Kojo, C., dan Rumokoy, F. (2016). Pengaruh Kompensasi, Beban Kerja, Dan Pengembangan Karir Terhadap Kepuasan Kerja Karyawan Pada Pt. Telekomunikasi Indonesia Tbk. Witel Sulut. Jurnal EMBA: Jurnal Riset Ekonomi, Manajemen, Bisnis dan Akuntansi Vol.4 No.4 Desember 2016, Hal. 1088 1097

Tulung, J.E. (2017). Resource Availability and Firm's International Strategy as Key Determinants Of Entry Mode Choice. Jurnal Aplikasi Manajemen, 15(1), 160-168.

Veithzal R. (2004). Kepemimpinan dan Perilaku Organisasi, Edisi Kedua PT Rajagrafindo Persada, Jakarta.

Yukl, G. (2005). Kepemimpinan Dalam Organisasi, Edisi kelima, PT Indeks, Jakarta. 